\title{
THROUGH SUFFERING, TOWARDS JOY. DIGGING INTO HAPPINESS WITH MICHEL HENRY
}

In Happiness And Contemporary Society : Conference Proceedings Volume (Lviv, March, 20-21, 2021). Lviv: SPOLOM, 2021. P. 62-64. https://doi.org/10.31108/7.2021.11

ISBN 978-966-919-697-2 
https://doi.org/10.31108/7.2021.11

\author{
CASUCCI Marco \\ PhD, Full Researcher \\ Department of Philosophy, Social Science and Education \\ University of Perugia (Perugia, Italy)
}

\title{
THROUGH SUFFERING, TOWARDS JOY. DIGGING INTO HAPPINESS WITH MICHEL HENRY
}

In this paper I want to focus my attention on Michel Henry's concept of joy as it is explained in his work The Essence of Manifestation. In this work the French philosopher analyses the essence of manifestation trying to overcome the common idea of manifestation itself intended as exteriority. For Henry the essence of manifestation lies on an inner and invisible revelation that cannot be shown and which is related to the invisible and immanent dimension of feeling. Suffering and joy become then the invisible feelings, which reveal the innermost essence of being as the origin of every manifestation.

Keywords: Essence, Manifestation, Being, Revelation, Feeling, Joy.

Michel Henry can be considered as one of the most influent French thinkers of the 20th century. Even if less known than his contemporaries such as Sartre, Merleau-Ponty, Ricoeur and Levinas, his contribution to thought is very relevant and deep.

The core of his thought is centred on the phenomenological question inherent the essence of manifestation. So, it is not an accident if the title of his first imponent work is The essence of manifestation. Here he tries to analyse the deepest sense of manifestation in western thought putting in light how it is pervasive in all its development and how it is unable to grasp its real fundament.

The Henry's argumentation on this can be summarised as follows: the western thought since its origins focused his attention on manifestation (on the phenomenon) as the enlightenment of being, as Heidegger, along with the phenomenological thought of Husserl, explained; but, even if thinking had the power of clarify the horizon of the manifestation of being, it was totally unable to uncover or unconceal the essence which lies "under" or "beyond" manifestation itself. So the essence of the unconcealment of being remains concealed - has Heidegger itself noticed - as the Abyss (der Abgrund) of being itself.

So what the western thought shows as its extreme limit and boundary is the impossibility to show the origin of the "show" of the world. Thinking is thus like an eye which cannot see itself or as a hand which cannot catch itself. Thinking is fundamentally given in its impossibility of climbing back to the origin of light which emanate from itself as the enlightenment of the world. In this sense Henry conceives the theoretical exercise as a sort of exteriorization which makes it possible the manifestation of the world, of being itself, bringing up with it the inability to think its real basis, which lies beyond the idea of manifestation, in a revelation which is totally different from the exteriority of the show of being.

In this sense the revelation is the essence of manifestation. Henry underlines the deep difference of sense which occurs between those two words which are normally considered as synonyms. In fact, if manifestation means the exteriority and the visibility 
of being, on the other hand revelation concerns the interiority of the invisible that cannot be manifested in the world. The revelation is always a re-velation of the hidden life, which lies beyond every kind of manifestation.

In this sense Henry's thought can be considered a "philosophy of life" in which life itself is the totality by virtue of which thinking takes its original foundation. But life it is not a show, life never shows itself in the world, but it remains always concealed in its hidden dimension which is the interiority of the revelation. Re-vealing means thus the escape from the duality of concealment and unconcealment, towards a salvation of the invisible which constitutes the deepest essence of every man.

So how it is possible for us to grasp the essence of revelation? How can we experience it if every experience is of the world, of its exteriority in which every essence is disclosed and scattered?

For Henry there is a kind of inner experience which remains in itself and never manifests in the world: the suffering. Suffering reveals itself because it cannot be totally exteriorized. Pain remains a part of the hidden life of the essence of revelation that never comes into light. Even if I can explain my pain, even if I can show my lamentations, my feeling never can be totally objectivated into a language - it remains always "my" suffering, my, pain, my feeling.

In the inner and hidden experience of suffering it is thus possible to discover the power of the feeling, of the mood by which we are affected as embodied and incarnated beings. The essence of revelation is thus the embodiment which allows us to suffer our feelings, to receive the invisible gift of life, which is our deepest ground and reality. Our passivity, our being exposed to suffering in our incarnated being means for Henry that we are capable to receive the revelation of the true sense of life which does not lies in the exteriority of the world, but in the hidden life of feeling.

That's why suffering for Henry must not to be considered as a mono-directional experience, suffering is not always "painful", is not always the "cause" of a depressed mood, but in its deepest essence is strictly related to joy, because it reveals us our true essence as receptive beings. Inasmuch as we are receptive, we are capable and powerful to receive the invisible gift of life which, through suffering, reveals us the deepest joy of life conceived as the definitive ground on which lies the essence of the manifestation.

Joy is considered by Henry as the "sparkle" which give rise to manifestation, it is the invisible fundament of all the visible world, an unmotivated experience which cannot be objectified nor manifested, because it never enters the horizon of the exteriority. Joy is the original "Parousia", the first "presence", that cannot be confused with representation because of its interiority: a presence of an invisible joy from which our personal life is revealed to itself.

Joy can be achieved only through suffering: that means that none can be really happy if he does not pass through the narrow door of passivity intended as the "place" where revelation can be experienced. This is the fundamental teaching of Christ as he said: "I am the door. If anyone enters by Me, he will be saved, and will go in and out and find pasture" (Jo, 10:9). The "door" is the "passion" of Christ through which it is possible to find the pasture of joy. The passivity of God in Christ, in his incarnated body, is the way though which it is possible for man to keep in touch with its original power of feeling in which happens the joy of being "sons of God".

With those words, certainly, we have passed the line that divides philosophy and theology, but we can say, however, that Henry has guided our course in this overcoming, 
by revealing us how to deep our philosophical experience, in order to achieve a more original joy as the fundamental part of our life.

\section{REFERENCES}

1. M. Henry, L'essence de la manifestation, 2 voll., PUF, Paris 1990.

2. M. Henry, Philosophie et phénoménologie du corps, PUF, Paris 1987.

3. M. Henry, C'est moi la verité. Pour une philosophie du christianisme, Seuil, Paris 1996.

4. M. Henry, Incarnation. Une philosophie de la chair, Seuil, Paris 2000.

5. M. Henry, Paroles du Christ, Seuil, Paris 2002. 